URL: http://www.dy.nayka.com.ua/pdf/3_2020/6.pdf (reference date: 29.09.2021)

4. Zahurska-Antoniuk V.F. National security and public administration system. Public administration: improvement and development. 2020. № 5. URL: http://www.dy.nayka.com.ua/pdf/5_2020/59.pdf (reference date: 29.09.2021).

5. Kokotun T. New in public administration reform. Financial control. 2019. № 7. P. 14-17.

6. Mochernyi S.V., Fomishyna V.M., Tyshchenko O.I. Economic theory for managers: Textbook. Kherson: Oldie-plus, 2006. 625 p.

7. Rodchenko I.Y. Priority areas for improving the system of public administration: scientific and practical recommendations in the context of reform. Public administration: improvement and development. 2019. № 2. URL: http://www.dy.nayka.com.ua/pdf/2_2019/32.pdf (reference date: 29.09.2021).

8. Shvebel V., Morozov O. On the complexation of models of socio-economic systems. Economist. 2020. № 4. P. 15-31.

DOI https://doi.org/10.30525/978-9934-26-147-3-7

\title{
ЗМІСТ ПУБЛІЧНОГО УПРАВЛІННЯ В ГАЛУЗІ ОСВІТИ
}

Галич О. А.

кандидат економічних наук, професор,

перший проректор Полтавського державного аграрного університету

Карапиш С. П.

ЗВО ступеня доктора філософії навчально-наукового інституту економіки, управління, права та інформачійних технологій

Полтавського державного аграрного університету

м. Полтава, Україна

У сучасних умовах розвитку української держави особливої актуальності набуває необхідність впровадження нових підходів до реформування публічного управління освітою як одного із основних напрямів побудови демократичної держави. Свропейська спрямованість розвитку України детермінує потребу в нових, адекватних сучасних умовах реформування та виважених нормативно-правових підходах. На сьогоднішній день вимагають трансформації та удосконалення форми і 
методи регулювання освітніх процесів у цій сфері, визначення ролі і місця публічної адміністрації в регулюванні сучасних освітніх процесів. Експерти наголошують, що переважна кількість проблем, які мають місце у системі сучасної освіти в Україні, існує через недостатню якість адміністрування відповідних публічних відносин.

Питанням адміністрування галуззю освіти було присвячено чимало наукових праць вітчизняних та зарубіжних вчених, серед яких М. Білинська, Ю. Битяк, В. Гаращук, В. Крижко, А. Куріченко, С. Майборода, О. Мельников, Н. Мирна, Л. Прокопенко, В. Сімонов, Г. Сидоренко та інші.

Термін "публічне управління" (англ. public management), який замінив термін “публічне адміністрування” (англ. public administration), вперше використовує англійський державний службовець Десмонд Кілінг у 1972 р. [1, с. 15]. “Публічне управління - це пошук у найкращий спосіб використання ресурсів задля досягнення пріоритетних цілей державної політики" [1, с. 15] (визначення Кілінга). Поява нової форми управління у публічній сфері була спричинена потребою модернізувати організаційні структури і процедури, які вони використовують, для того, щоб усі інституції публічної сфери працювали краще. Публічне управління стосується ефективного функціонування всієї системи політичних інституцій. Ключовим аспектом державного управління $\epsilon$ держава, у той час як ключовим аспектом публічного управління $\epsilon$ народ. Один із сучасних дослідників публічного управління Гірт Букерт наголошує на тому, що “публічне управління не є якимось нейтральним, технічним процесом, натомість $є$ діяльністю, яка тісно пов'язана 3 політикою, законом та громадянським суспільством” [2, с. 26].

В Україні управління у сфері освіти визначається ст. 62 Закону України «Про освіту» [3]. До органів управління належать: Кабінет Міністрів України; центральний орган виконавчої влади у сфері освіти і науки; центральний орган виконавчої влади із забезпечення якості освіти; постійно діючий колегіальний орган у сфері забезпечення якості вищої освіти; державні органи, яким підпорядковані заклади освіти; Верховна Рада Автономної Республіки Крим; Рада міністрів Автономної Республіки Крим; органи місцевого самоврядування. Повноваження цих органів визначені відповідно до Закону України «Про освіту» (ст. 63 - ст. 67) [3]. I хоча поняття «публічного управління» та «публічного адміністрування» не визначаються цим законом, та принципи його спостерігаються наскрізно у ст. 68 - ст. 73: відкритість органів управління у сфері освіти; громадське самоврядування та державно-громадське управління у сфері освіти; громадський нагляд ; інститут освітнього омбудсмена. 
Засадами державної політики у сфері освіти є: людиноцентризм; верховенство права; забезпечення якості освіти та якості освітньої діяльності;

забезпечення універсального дизайну та розумного пристосування; різноманітність освіти; цілісність і наступність системи освіти; прозорість і публічність прийняття та виконання управлінських рішень; відповідальність і підзвітність органів управління освітою та закладів освіти, інших суб'єктів освітньої діяльності перед суспільством; інституційне відокремлення функцій контролю (нагляду) та функцій забезпечення діяльності закладів освіти; академічна доброчесність; академічна свобода; фінансова, академічна, кадрова та організаційна автономія закладів освіти у межах, визначених законом; гуманізм; демократизм; єдність навчання, виховання та розвитку; формування громадянської культури та культури демократії; невтручання політичних партій в освітній процес; державно-громадське управління; державно-громадське партнерство; державно-приватне партнерство; сприяння навчанню впродовж життя; інтеграція у міжнародний освітній та науковий простір; нетерпимість до проявів корупції та хабарництва; доступність для кожного громадянина всіх форм і типів освітніх послуг, що надаються державою та інші [3]. Розширюються та підтверджуються дані принципи у ЗУ «Про повну загальну освіту» [4] та 3У «Про вищу освіту» ( у редакції 02.10.2021) [5].

До ознак адміністрування галуззю освіти можна віднести:

регулювання - регулювання відносин освітніх процесів (навчання, виховання, професійної, наукової та загальнокультурної підготовки здобувачів освіти);

колективність - проявляється через колективну діяльність державних службовців, керівників закладів освіти та педагогів;

постійність - постійне координування та регулювання діяльності закладів освіти;

імперативність - має вплив на взаємовідносини у сфері освіти, підпорядковує волю учасників, формуючи іiі;

педагогічність - механізм управління орієнтований на творчоінноваційний розвиток освіти, iї гуманізацію та демократизацію [6].

Цікавим поняттям $є$ «публічна адміністрація». Чи можна вважати керівника в галузі освіти (директора, ректора та інших керівників структурних підрозділів) публічними адміністраторами? У процесі наших наукових пошуків, ми зупинилися на наступному розкритті змісту: «Публічна адміністрація, займаючись організацією та урегулюванням публічних справ, діє у публічних інтересах. Метою діяльності публічної адміністрації є задоволення публічного інтересу», 
що частково реалізується у функціях керівника закладу освіти, відповідно до Концепції нової української школи [7].

Перспективи подальших досліджень потребують докладного вивчення в Україні змісту реалізації публічного управління та адміністрування в галузі освіти, виокремлення і систематизацію кращих зарубіжних практик.

\section{Література:}

1. Keeling D. Management in Government / D. Keeling (1972), London: Allen \& Unwin

2. Bouckaert G. Modernizing the Rechtsstaat: Paradoxes of the Management Agenda / G. Bouckaert. - Berlin : Duncker \& Humblot, 2002.

3. Закон України «Про освіту» від 05.09.2017 № 2145 VIII, із змінами (витяг). Верховна рада Украӥни. Офічійний вебпортал парламенту Украӥни. URL: https://zakon.rada.gov.ua/laws/show/2145 19 (дата звернення 04.10.2021)

4. Закон України «Про повну загальну середню освіту» від 16 січня 2020 року № 463-IX, із змінами (витяг) https://zakon.rada.gov.ua/ laws/show/463-20 (дата звернення 04.10.2021)

5. Закон України «Про вищу освіту» від 28.12.2014 №1556 VII, iз змінами (витяг). Верховна рада Украӥни. Офічійний вебпортал парламенту України. URL: https://zakon.rada.gov.ua/laws/show/155618\#Tехt (дата звернення 04.10.2021)

6. Савіщенко В. М. Адміністративно-правове забезпечення освіти та науки в Україні : монограф. / В. М. Савіщенко. - Дніпропетровськ : Дніпроп. держ. ун-т внутр. справ ; Ліра, 2015. - 372 с.

7. Про схвалення Концепції реалізації державної політики у сфері реформування загальної середньої освіти “Нова українська школа" на період до 2029 року. URL: http://ru.osvita.ua/legislation/Ser_osv/54258/ (дата звернення 04.10.2021) 